\title{
AREG Gene
}

National Cancer Institute

\section{Source}

National Cancer Institute. AREG Gene. NCI Thesaurus. Code C20155.

This gene plays a role in the regulation of epithelial cell growth. 